DOI 10.30740/jee.v1i1.p27-36

\title{
IMPLEMENTATION OF GEOGEBRA HELP INKUIRI METHOD TO INCREASE ABILITY OF MATHEMATICAL PROBLEMS CLASS STUDENTS XI-TEI B SMK IT DEVELOPMENT OF CIMAHI CITY ON MATERIALS RULES OF SINUS AND COSINUS
}

\author{
Dena Handriana ${ }^{1}$, Rosalina Rolina ${ }^{2}$, Asep Mulyana ${ }^{3}$ \\ ${ }^{1}$ IKIP Siliwangi Bandung \\ ${ }^{2}$ SMK TI Pembangunan Cimahi \\ ${ }^{3}$ SMK Kesehatan Bakti Assyukur \\ ${ }^{1}$ denahandriana91@gmail.com, ${ }^{2}$ maezarou@gmail.com, ${ }^{3}$ asep_mulyana1@yahoo.co.id,
}

Received: January 08, 2018; Accepted: June 27, 2018

\begin{abstract}
This research is an action research study. The problem formulated in this research is whether through geographical assisted inquiry method, mathematical problem solving ability of students of class XITEI B SMK TI Development on the material of sinus and cosine rules can be improved? The aim is to examine the improvement of problem solving ability of students of class XI-TEI B SMK IT Development of Cimahi through geogebra assisted inquiry method .This research was conducted on the students of class XI-TEI B SMK IT Development Cimahi academic year 2017-2018 with the number of students 24 people. The instrument used is a test of learning outcomes as a test of students' mathematical problem solving abilities of the sin and cosine rules, cycle I , II and II tests (after giving of action) and observation sheet for teachers and students for the conditions of action implementation. R prosedu study consisted of: (1) planning, (2) p elaksanaa $\mathrm{n}$ action, (3) observation and evaluation, and (4) $r$ efleksi. The average value of the results of the test cycle II, which is 30,25 increased by 16.17 compared to the average value of the results of the test cycle I, namely 14.08. And the average value of the third cycle test results that is 76,75 increased by 46.50 . Based on the performance indicators, it is concluded that the mathematical problem solving ability of students of class XI-TEI B SMK TI Pembangunan Cimahi on the material of sinus and cosine rules can be improved through geogebra assisted inquiry method.
\end{abstract}

Keywords: Mathematical Problem Solving, Inquiry Method, Geogebra.

\begin{abstract}
Abstrak
Penelitian ini adalah penelitian tindakan kelas. Masalah yang dirumuskan dalam penelitian ini adalah apakah melalui metode inkuiri berbantuan geogebra, kemampuan pemecahan masalah matematik siswa kelas XI-TEI B SMK TI Pembangunan pada materi aturan sinus dan cosinus dapat ditingkatkan? Tujuannya untuk menelaah peningkatan kemampuan pemecahan masalah matematik siswa kelas XITEI B SMK TI Pembangunan Cimahi melalui metode inkuiri berbantuan geogebra. Penelitian ini dilaksanakan pada siswa kelas XI-TEI B SMK TI Pembangunan Cimahi tahun pelajaran 2017-2018 dengan jumlah siswa 24 orang. Instrumen yang digunakan adalah tes hasil belajar sebagai tes kemampuan pemecahan masalah matematik siswa mengenai soal aturan sinus dan cosinus, tes siklus I, II dan III (setelah pemberian tindakan) dan lembar observasi bagi guru dan siswa untuk kondisi pelaksanaan tindakan. Prosedur penelitian terdiri dari: (1) perencanaan, (2) pelaksanaan tindakan, (3) observasi dan evaluasi, dan (4) refleksi. Nilai rata-rata hasil tes siklus II, yaitu 30,25 meningkat sebesar 16,17 dibanding nilai rata-rata hasil tes siklus I, yaitu 14,08. Dan nilai rata-rata hasil tes siklus III yaitu 76,75 meningkat sebesar 46,50. Berdasarkan indikator kinerja, disimpulkan bahwa
\end{abstract}


kemampuan pemecahan masalah matematik siswa kelas XI-TEI B SMK TI Pembangunan Cimahi pada materi aturan sinus dan cosinus dapat ditingkatkan melalui metode inkuiri berbantuan geogebra.

Kata Kunci: Pemecahan Masalah Matematik, Metode Inkuiri, Geogebra.

How to Cite: Handriana, D., Rolina, R., \& Mulyana, A. (2018). Implementation Of Geogebra Help Inkuiri Method To Increase Ability Of Mathematical Problems Class Students Xi-Tei B Smk It Development Of Cimahi City On Materials Rules Of Sinus And Cosinus. Journal of Educational Experts (JEE), 1 (1), 27-36.

\section{INTRODUCTION}

The importance of problem- solving abilities is expressed by Branca, as quoted by Effendi (2012: 2), that problem-solving skills are the heart of mathematics. Student problem solving skills are related to the stage of solving mathematical problems. According to Polya (1973: 6), the mathematical problem solving stage includes: (1) understanding the problem, (2) making a plan of completion, (3) executing the plan, and (4) looking back. This is intended so that students are more skilled in solving mathematical problems, that is skilled in carrying out procedures in solving problems quickly and carefully as disclosed by Hudojo, as quoted by Yuwono (2010: 40). Problem solving is important in the purpose of mathematics education because in everyday life people can never escape from problems.Problem solving activity can be considered a basic human activity. The problem must be sought by the way man himself, if not to be defeated by life.

But the reality shows that students' mathematical problem solving ability is less encouraging. Student achievement in mathematics is generally still low. (Sumarmo, 1993) reported that the problem solving ability of high school students was not satisfactory. This situation is also reflected on the results of $\mathrm{Na} s$ ional Exam (UN), there are still many students failed in mathematics. In addition, in mathematics competitions such as mathematics olympiad, the problem-solving problem of mathematical problem solving is generally not successfully answered students correctly. The above facts show that basic mathematical skills such as mathematical problem solving are still far from being expected in standard contents and process standards. The low average student learning outcomes at the same time become a picture of the quality of our mathematics education is not good and this can not be considered trivial so it needs to get more serious attention.

Based on the information from teachers who taught at the school in previous years, the ability to solve students' mathematical problems are still low. For example on workmanship: Grandfather has a triangular playground known for its surroundings is $16 \mathrm{~m}$. The playground is limited to points $\mathrm{A}, \mathrm{B}$ and $\mathrm{C}$. The length of the $\mathrm{BC}$ side is $3 \mathrm{~m}$ longer than the $\mathrm{AC}$ side length, while the length of the $\mathrm{AB}$ side is $4 \mathrm{~m}$ longer than the $\mathrm{AC}$ side length. Determine the area of the playground the!

Results of student answers are shown in Figure 1.1 below.

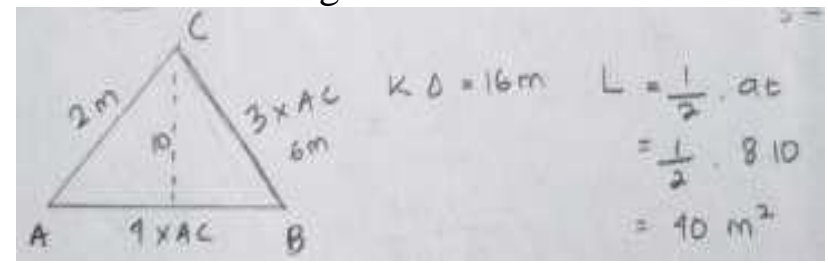

Figure 1. Example of student work result 
In Figure 1 above, it appears that the student does not write down what is known and asked from the problem, meaning that students can not understand problem. Besides, students can not explain whatconcept is used in solving the problem, meaning that students can not plan completion and execution of the settlement plan. When viewed from the picture, students also have not concluded the results obtained, meaning the students have not able to see back results and processes. Though understanding the problem, plan settlement, execute completion plan, and view return results and processes including part of mathematical problem solving according to Polya. Most students have problems when solving the problem mathematics. Students tend to use a formula or a quick way is commonly used rather than using procedural steps from solving math problems. Meanwhile, based on interviews with SMK IT Development mathematics teacher, the average Deuteronomic value The odd semester of Year X students of the academic year 2016/2017 is 55.05 means still under KKM (Minimum Criteria Completeness) and ability solve the problem on the trigonometric material is still weak, therefore it is necessary made improvements for material mastery and problem solving trigonometry may increase. Master participates in the refining process mastery of trigonometric material, ie by improving activities learning in school.

One effort to improve the learning process is by choose the appropriate and innovative learning model in learning mathematics. One of the learning models that can be applied for to improve problem solving ability is through geogebra assisted inquiry study method .

One of the goals of an estab learning through inquiry method is that students learn scientific methods and can apply them in other situations. According Ruseffendi (1991: 335) on the method of inquiry itself there are four stages of activity are :(1) s is stimulated by the teacher with the problem; (2) s ISWA determine the procedures locate and gather the necessary information; (3) s ISWA live on knowledge gained by way of inquiry has just done; (4) S ISWA held on methods of inquiry and analysis procedures found to be a general method that can be applied to a new atmosphere. Learning with inquiry method is expected to make the students can build their own knowledge that is expected to memory and understanding of the concepts he studied can be permanently attached to the students themselves.

Other processes that can create math learning with inquiry methods are more meaningful and interesting among others is by using information technology that developed today, for example by using computers that have been equipped with learning software. As Ormrod (2009: 175) states that some computer programs have been able to improve high-level thinking (eg problem-solving) in the context of authentic or game-like tasks.

The advantages of using geogebra software are: (1) 1 geometric paintings that are usually produced quickly and thoroughly compared with pencils, rulers and runs; (2) a danya animation facility and manipulation movements on geogebra can provide a clearer visual experience to the students in understanding the geometry concept; (3) can be used as an evaluation to ensure that the paintings that have been made are correct, and; (4) make it easier for teachers / students to investigate or demonstrate the properties that apply to an object of geometry.

By using GeoGebra software, students can: (1) m enemukan own concept of the material being studied and build knowledge; (2) m elakukan eksploras i and observation with ease; (3) $\mathrm{m}$ enyelesaikan math quickly $\mathrm{d}$ an accurate learning, and; ( 4 ) b is more positive toward mathematics. 
Based on the above description, geo - threaded inquiry learning meted ode is expected to make students challenged to use their reasoning which then tries to solve the problem given . To examine more deeply about learning with the help of software GeoGebra's, pen eliti interested in conducting research with the title "Implementation Method inquiry assisted GeoGebra to Improve Ability Problem Solving Math Student Class XI-TEI B and vocational IT Development Cimahi to Content Rules Sine and Cosine".

\section{PROBLEM SOLVING SKILL}

Mathematical problem solving skills are the skills or the potential of the students in solving word problems, solve problems that are not routine, apply mathematics $\mathrm{m}$ dal a daily life or other circumstances, and s proves fish, create or test the conjecture.

The indicators of mathematical problem-solving ability are as follows: (1) understand the problem, that is, to identify the adequacy of the data to solve the problem so as to obtain a full picture of what is known and stated in the problem, (2) plan the settlement, which is to determine the settlement measures, the selection of concepts, equations and theories is appropriate for each step, (3) m running the plan, that is, to carry out the settlement based on the steps that have been designed using the concepts, the same as the theory chosen, and (4) see what which has been done is the examination stage, whether the rare-step settlement has been ritually appropriate so that it can re-examine the truth of the answer that ultimately makes the final conclusion.

\section{METHOD OF INQUIRY LEARNING}

Learning with the method of inquiry is a series of activities that emphasize student to be able to critically and analytically ask questions about a problem and then seek out and investigate until dapat find a solution themselves.

\section{RESEARCH METHODS}

This research is a classroom action research, ie research that is intended to provide information on how appropriate action to improve teacher ability and student activeness. Therefore, this research is focused on actions as an appropriate effort to improve teachers' ability and student activeness in learning.

This research was conducted from 9 November 2017 until 20 November 2017 in odd semester of academic year 2017 -2018 at SMK IT Development Cimahi with subject of research is student of class XI-TEI B with number of student counted 24 person consisting 19 men and 5 woman.

The instrument used is the test of learning outcomes as a test of students' mathematical problem solving abilities on the rules of sine and cosine, cycle tests I, II and II I (after giving the action); and observation sheets for teachers and students for the conditions of action implementation .

Sources of data are research personnel consisting of teachers and students, the type of data that is quantitative data and qualitative data obtained through test results, observations and journals. And the method of data collection are: (1) $d$ ata about learning condition of sinus and cosine rules with geographic assisted inquiry method taken using observation sheet include 
observation to gur $\mathrm{u}$ and students;(2) $\mathrm{d}$ ata about the learning achievement was taken using the test included the first cycle test, the I cycle test I and the third cycle test, and; (3) d ata about the reflection taken by using the journal.

Data obtained from this research that comes from the test cycle I, the test cycle II and test cycle III . All data is processed by using microsoft excel by calculating the average and see the average comparison and percentage of students' learning mastery from each cycle.

\section{RESULTS AND DISCUSSION}

\section{Results}

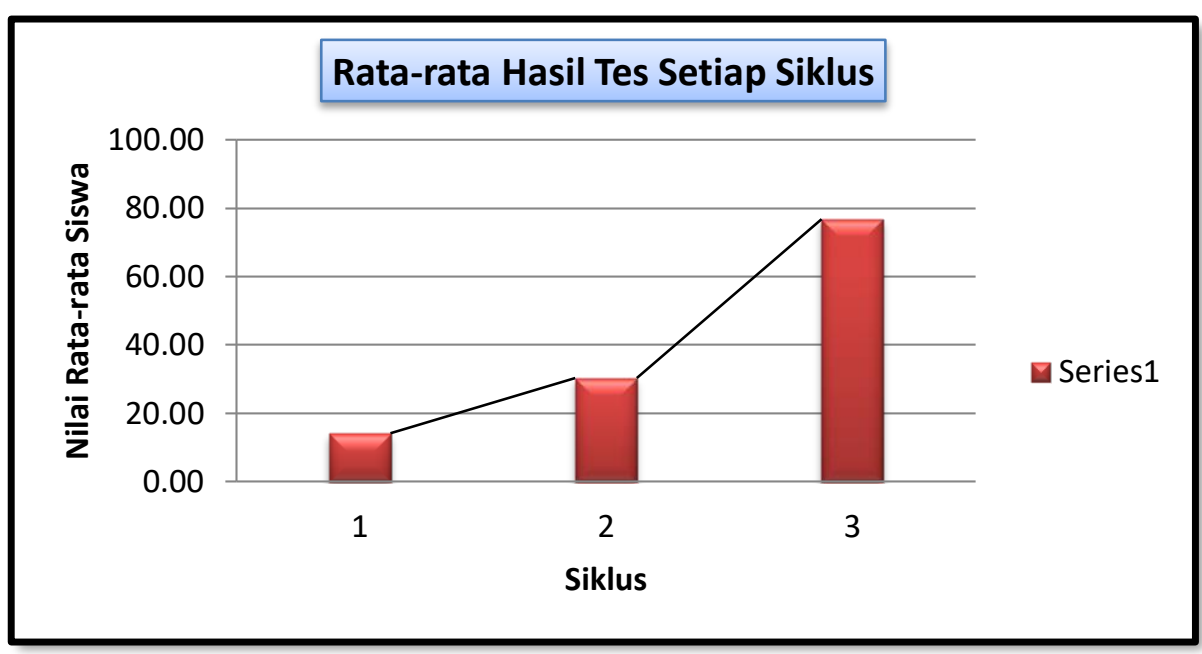

Figure 2. The average value of each cycle test

From the picture above diagram shows that:

1. The results of the first cycle of research is the average value of the first cycle test results that is equal to 14,08 with learning completeness of $55.03 \%$.

2. The results of the research cycle II is the average value of the second cycle test results that is 30,25 and an increase of 16.17 from cycle I for 14.08 with $29.75 \%$ complete learning.

3. The results of the third cycle research is the average value of the third cycle test results that is 76,75 and an increase of 46.50 from cycle I I for 30.25 with learning completeness of $83.93 \%$.

\section{Discussion}

\section{Results of Cycle I Research}

a. Planning ( Plan )

The things that are done at this stage is the making of learning implementation plan (RPP) based on the syllabus used as the research reference. The RPP made for cycle I consists of 1 encounter on "Sinus and Cosinus Rules" material using geographical assisted inquiry method . Based on the learning steps pad a RPP cycle I. Application of the method of inquiry assistedGeoGebra in the first cycle was conducted by lecture, question-answer, and dis kusi and has indicators: (1) m enyebutkan comparison trigonometry to a right triangle; (2) discuss the problem to get the concept of sinus rules; (3) calculating the side of the triangle by using the concept of sinus uran; (4) determining the angle of the triangle by using the concept of the sine rule, and; (5) apply the concept of sinus rules in solving daily life problems. 
Then the researcher makes an observation sheet addressed to teachers and students (observed aspects are based on learning steps in RPP), preparing a reflection journal sheet and designing an evaluation tool for the I cycle test.

Another preparation is to further strengthen the knowledge and understanding of teachers about the implementation of learning with geographical assisted inquiry approach.

\section{b. Implementation of Action ( Do )}

Implementation of the action is done by the teacher of mathematics to weld XI-TEI B SMK IT Development Cimahi, while researchers act as observers ( observer ). The first cycle of learning is carried out in a single meeting.

The first class presentation was held on Thursday 9 November 2017 with the material "Sinus Rules". Prepared RPPs use geogebra -assisted inquiry method with lecture and discussion methods.

After the presentation of this first class, teachers and researchers discuss some of the shortcomings that occur in learning activities. In this case the teacher still gives less opportunity to the students to ask and respond. Yet if only this is done will increase knowledge and mastery of student concepts for the better. Classroom learning is ensured to be more creative and fun. In addition,teachers should be better able to motivate students to solve stories, solve problems that are not routine, apply mathematics in the life of a day or other circumstances, and prove, create or test conjecture. From the results of this discussion, the teacher is willing to correct the deficiencies at the next meeting.

\section{c. Evaluation ( See )}

After one meeting to complete basic competence "Calculating the side and determining the angle of the triangle $\mathrm{d}$ by using the concept of the sine rule" which is the elaboration of the standard of competence "Describing and analyzing the rules of sine and cosine and applying them in determining the area of triangle", evaluated by the name of the first cycle test on Thursday, November 2017. This activity was conducted to find out how far the solution of mathematical problems of students on the material of "Sinus and Cosinus Rules" after learning using geographical assisted inquiry method.

The test results show that students have not been able to demonstrate their mathematical problem solving ability. The results of this test also shows students' mastery of classical to the subject matter. So there needs to be an addition of action so that they really understand the material "Sinus and Cosinus Rules" is.

The average test cycle I score is 14,08 with a learning mastery of $55.03 \%$. This shows that the average value of mathematical problem solving ability of grade XI-TEI B students of SMK TI Pembangunan Cimahi on the material is still very low. In addition, the results of the first cycle test scores are also important to see students' ability in mathematical problemsolving abilities. It aims to know the learning outcomes with geographic assisted inquiry method for each meeting conducted.

\section{Cycle Research Result II}

a. Planning ( Plan )

Based on the results of observation and evaluation on the action of cycle $I$, the researcher together with the teacher planning the action cycle II, so that the weaknesses that occur in the 
implementation of the action of cycle I can be improved and mehcapai maximum results. The things that teachers need to improve on the implementation of the second cycle action are as follows: (1) g uru must be able to organize the time well as planned in the learning scenario; (2) should be a member i g uru students the chance to put forward the idea of the ones on the sample questions is a core medium of learning. This is to foster the spirit of the students in understanding and problem-solving plan although essentially the teacher must notify and menjela scan right way, and; (3) guru should provide more guidance to students both individuals and groups in the learning process with geographical assisted inquiry method .

The things that are done at this stage is the making of learning implementation plan (RPP) based on the syllabus used as the research reference. The RPP made for cycle I I consists of 1 encounter on "Sinus and Cosinus Rules" material using geographical assisted inquiry method . Based on the learning steps RPP first cycle I. The application of geogebra assisted inquiry method in cycle I was done by geographical assisted inquiry method and has indicators: (1) $\mathrm{m}$ endiskusikan issues in order to get the concept of the rule of cosines; (2) calculating the triangular side using the concept of cosine rules ; (3) determining the angle of the triangle $\mathrm{d}$ by applying the concept of co sinus rules, and; (4) apply the concept of co sinus rules in solving daily life problems.

Then the researchers made the observation sheet addressed to teachers and students (based on the observable aspects of learning steps on RPP), prepared a reflection journal sheet and designed the evaluation tools to test the first cycle I.

Another preparation is to further strengthen the knowledge and understanding of teachers about the implementation of learning with geographical assisted inquiry approach.

\section{b. Implementation of Action ( Do )}

Implementation of the action is done by the teacher of mathematics class XI-TEI B SMK IT Development Cimahi, while researchers act as observers ( observer ). Action learning cycle I firstimplemented in one meeting.

The presentation of the second class is held on Monday, November 13, 2017 with the material "Cos Inus Rules ". Prepared RPP using geogebra assisted inquiry method .

After the presentation of this second class, researchers assessed the teacher is good enough in directing students to ask questions and members i responses. Teachers provide some examples and work with students in the hope that students are able to understand the material. Likewise with learning steps on core activities such as cycle I, then students' selfunderstanding strategies as well as teachers optimize through geogebra software. These strategies are to ask the students to conclude, solve the problems in LKS 1.2, present the work of the group, re-explain the knowledge obtained and predict the difficult questions of some given problem beforehand.

At the end of the learning cycle II, teachers together with students summarize the results of discussion and reflection. The teacher members to work i PR students to understanding and solving mathematical problems become better students. Teacher ends the lesson with advice and salam closes. Observation sheets for teachers and students are still used by researchers to observe the learning process that lasts from start to finish. 


\section{c. Evaluation ( See )}

In this second cycle, learning is done by one meeting to complete basic competency "Calculating side and determining angle of triangle $d$ by using concept of co sinus rule " which is elaboration of competency standard "Describe and analyze the rules of sinus and cosinus and apply it in determining area triangle ", the evaluation was conducted with the test of cycle I I on Monday, November 13 , 2017. This activity was conducted to find out how far the solution of mathematical problems of students on the material" Sinus and Cosine Rules "after learning usinggeogebra assisted inquiry method .

The test results indicate that the students have been able to demonstrate their mathematical problem solving ability. The results of this test also shows students' mastery of the classical subject matter and still must be given further action. So there needs to be an addition of action so that they really understand the material "Sinus and Cosinus Rules" is.

The average I cycle test score I is 30,25 with a learning mastery of $29.75 \%$. This shows that the average value of mathematical problem solving ability of students of class XI-TEI B SMK TI Development of the material still has been an increase of 16, 17 from cycle I of 14,08 although in learning completeness decrease equal to 25,28\%. In addition, the results of the test scores the first cycle I is also important to look at the students' skills in mathematical problem solving ability. It aims to know the learning outcomes with geographic assisted inquiry method for each meeting conducted.

\section{Results of Cycle I Research II}

\section{a. Planning ( Plan )}

Based on the results of observation and evaluation on the action of cycle I I , the researcher and the teacher plan the action of cycle II I , so that the weaknesses that occur in the implementation of the I cycle action I can be improved and achieve maximum results. Things that should be corrected by the teacher on the implementation of the second cycle of the first of them as follows: (1) guru should be able to organize your time well as planned scenario elajaran pemb; (2) g uru should give the students an opportunity to express their initial ideas about examples of problems that are the core media of learning. This is to foster the spirit of the students in understanding and problem-solving plan although essentially the teacher must notify and menjela scan right way, and; (3) guru should provide more guidance to students both individuals and groups in the learning process with geographical assisted inquiry method.

The things that are done at this stage is the making of learning implementation plan (RPP) based on the syllabus used as the research reference. The RPP made for cycle II I consists of 1 encounter on the material "Sinus and Cosinus Rules" using geographical assisted inquiry method . Based on the learning steps RPP second cycle first. Application of the method of inquiry assistedGeoGebra on the second cycle I do with GeoGebra-aided method of inquiry and has indicators: (1) m enentukan area of a triangle using the concept of rule of sines and cosines.

Then the researchers made the observation sheet addressed to teachers and students (based on the observable aspects of learning steps on RPP), prepared a reflection journal sheet and designed the evaluation tools to test the second cycle first.

Another preparation is to further strengthen the knowledge and understanding of teachers about the implementation of learning with geographical assisted inquiry approach. 


\section{b. Implementation of Action ( Do )}

Implementation of the action is done by the teacher of mathematics class XI-TEI B SMK IT Development Cimahi, while researchers still act as observers ( observer ). The action of learning cycle II I was conducted in one meeting.

The third class presentation is held on Thursday, November 16 , 2017 with the material "Cosine Rules". Prepared RPP using geogebra assisted inquiry method .

After the presentation of this second class, $\mathrm{p}$ eneliti assess teachers have been very good in directing students to ask questions and members i responses. Teachers provide some examples and work with students in the hope that students are able to understand the material. Likewise with learning steps on core activities such as cycle I I, then students' selfunderstanding strategies as well as teachers optimize through geogebra software. These strategies are to ask the students to conclude, solve the problems in LKS 1.3, present the work of the group, re-explain the knowledge obtained and predict the difficult questions of some of the problems given earlier.

At the end of the second cycle of the first learning this together student teacher summarizes the results of the discussion and reflection. The teacher members to work i PR students to understanding and solving mathematical problems become better students. Teacher ends the lesson with advice and salam closes. Observation sheets for teachers and students are still used by researchers to observe the learning process that lasts from start to finish.

\section{c. Evaluation ( See )}

In cycle I I I this, learning to do as much as one-off meeting to resolve the basic competence "Determining the area of the triangle $d$ ith use the concept of rule of co sinus" which is a translation of the standard of competency "To describe and analyze the law of sines and cosines and apply in determining the area of a triangle ", conducted the evaluation as test cycle I I I on Thursday, tanggal 16 November 2017. this activity is conducted to determine the extent of students' mathematical problem solving on the matter" Sine and Cosine Rules "after learning the method of inquiry assisted GeoGebra.

The test results indicate that the students have been able to demonstrate their mathematical problem solving ability. The results of this test also show students' mastery of the classical material of this "Sinus and Cosinus Rules".

The average test value of cycle II I is 76,75 with a learning mastery of $83.93 \%$. This shows that the average value of mathematical problem solving ability of students of class XI-TEI B SMK IT Development of Cimahi to the material still there has been another increase of 46 , 50 from cycle I I of 30,25. In addition, the results of the second cycle test score I is also important to see students' ability in mathematical problem solving abilities. It aims to know the learning outcomes with geographic assisted inquiry method for each meeting conducted.

\section{d. Reflection}

Reflection on this third cycle, showing encouraging results, both for teachers and for researchers. The results of observations conducted by researchers showed that geographic assisted inquiry method applied in class XI-TEI B SMK IT Development Cimahi provide excellent results. Thus, the hypothesis of this research action has been achieved blah students mathematical problem solving skills of class XI-TEI B SMK IT Development Cimahi on the 
material rules of sinus and cosine can be improved through geographic assisted inquiry method .

This is in line with the relevant research conducted by Yenny Meidawati (2014) in SMP Negeri 1 Bulok Tanggamus concluded that the learning approach guided inquiry affect the ability of solving mathematical students because of the difference in average increase problem-solving ability mathematics students who use learning approaches guided inquiry is higher than students who use regular learning approach.

Furthermore, the research dilakuk 's by Sulfiaty Idris (2015) at SMAN 1 Tompobulu concluded that the average value of the results of students of class XII IPA 1 SMA Negeri 1 Tompobulu final test cycle I is 59.14 with the medium category. while the average value of student learning outcomes in the second cycle is 73.64 with the high category, so that the students of class XII IPA 1 SMA Negeri 1 Tompobulu in the first cycle and the second cycle increased through inquiry learning strategies and applications GeoGebra.

\section{CONCLUSION}

Based on the analysis and discussion, it can be concluded that the ability of mathematical problem-solving class XI student of SMK TI-TEI B Construction of Cimahi on the material rules of sines and cosines can be improved through the method of inquiry assisted GeoGebra.

\section{REFERENCES}

Effendi, S. (2012). Survey Research Methods. Jakarta: LP3ES.

Idris, S. (2015). Improved Learning Outcomes Linear Program through Inquiry Learning Strategy and GeoGebra Class XII IPA 1 SMA Negeri 1 Tompobulu. Indonesian Digital Journal of Mathematics and Education, Vol. 2 No. 3. [Online] http://idealmathedu.p4tkmatematika.org/ - Downloaded dated December 14, 2017.

Meidawati, Y. (2014). Effect of Guided Inquiry Learning Approach to Mathematics Problem Solving Ability Improvement Junior high school students. Journal of Education and Teaching, Vol. $\quad 1 \quad$ No. $\quad 2 . \quad$ [Online] http://pasca.ut.ac.id/journal/index.php/JPK/article/view/51 - Downloaded dated December 14, 2017

Ormrod, JE (2009). Psychology of Education: Helping Students Grow. Jakarta: Erland.

Polya, G. (1973). How to Solve It: A New Aspect of Mathematical Method (2 nd Ed). Princeton New Jersey: Princeton University Press.

Ruseffendi, ET (1991). Introduction to Helping Teachers Develop Competence in Teaching Mathematics to Improve the CBSA. Bandung: Tarsito.

Sumarmo. U. (1993). Role of Logical Ability and Activity Study on Mathematical Problem Solving Ability in High School Students in Bandung municipality. Bandung Teachers' Training College Research Report: Unpublished.

Yuwono, A. (2010). Profile High School Students in Solving Mathematical Problems Viewed from the Personality Type. Thesis. Surakarta: Eleven University in March. 